\title{
EVALUATION OF SWITCHGRASS SOURCE MATERIAL PRODUCTIVITY FOR PLANT BREEDING
}

\author{
Maksym Kulyk ${ }^{1}$ \\ Olha Dinets ${ }^{2}$ \\ Ilona Rozhko ${ }^{3}$
}

DOI: https://doi.org/10.30525/978-9934-588-15-0-133

\begin{abstract}
The scientific research envisages: to study switchgrass varietal specimens according to economically valuable traits as well as to distinguish the most yielding ones, which have a high yield of certified seed in relation to the weather conditions of the vegetation period by HTC (hydrothermal coefficient). The research object is switchgrass varietal specimens (Zoriane, Morozko, Liniia 1307 and Cave-in-Rock), biometric indicators, seed yield, and weather conditions. The methods used in the research are general and special: methods of scientific research in agronomy, laboratory-field method - to determine the quantitative indicators of vegetative and generative parts of plants and the weight of 1000 seeds, quantitative-weight methods - to establish crop productivity and yield of certified seed; statistical processing of research results was performed by a dispersion analysis and variation statistics. Research results. Variety Zoriane and Liniia 1307 formed the highest quantitative indicators of the vegetative (height of plants, number of stems and leaves and length of flag leaf) and generative part of plants (length and width of panicle, number of twigs of the first order and number of panicles and weight of seeds from panicle) independently of the cultivation conditions. The impact of biometric (quantitative) indicators of the generative part of plants, in close relation with the weather conditions by HTC during the vegetation period, on the seed productivity, which affect the total crop yield, has been determined according to the research
\end{abstract}

\footnotetext{
${ }^{1}$ Doctor of Agricultural Sciences, Associate Professor, Senior Research Assistant of the Research Department, Poltava State Agrarian Academy, Ukraine

${ }^{2}$ Assistant of the Department of Selection, Seed Science and Genetics,

Poltava State Agrarian Academy, Ukraine

${ }^{3}$ Postgraduate of the Department of Selection, Seed Science and Genetics, Poltava State Agrarian Academy, Ukraine
} 
results. Seed yield of switchgrass varietal specimens by the determination coefficient (d) depends on: 53-59\% - the number of twigs of the first order, $48-52 \%$ - the number of panicles, $12-21 \%$ - the seeds size, and 6-12\% - the length and width of panicle. Conclusions. Variety Zoriane and Liniia 1307, which produce weighty seeds, high seed yield (more than $500 \mathrm{~kg} / \mathrm{ha}$ ) of certified seed (about 65\%) and can be used in further breeding work to create and expand switchgrass assortment have been distinguished. In future, this will allow to obtain seed material of high quality at no additional cost, to establish new energy plantations for the production of plant biomass for energy purposes and additional products for various industries.

\section{Introduction}

In Ukraine, along with food security, the energy sector is equally important in order to ensure high indicators of economic efficiency of agriculture. Energy sector requires comprehensive study and implementation of plant energy resources. Plants that accumulate solar energy are a renewable resource and can be used as an alternative energy source for agriculture, industry, housing and communal services. In this regard, energy crops are the most effective, as their crops are established on the marginal lands, and they do not compete with food crops. Among the energy crops, switchgrass holds the leading position in terms of integrated use of phytomass: for use in animal husbandry, pulp production, production of biofuels, etc. [1-6].

However, the biofuel direction of switchgrass use needs further researches to study the ways to increase biomass yield and to improve seed productivity of the crop. Therefore, studying the ways of obtaining switchgrass material of high quality in order to establish new energy plantations is a relevant area of research as well.

\section{Literature review}

Today, scientists have determined that Ukraine has a strong potential for agrobiomass of crops and phytomass of energy crops being cultivated on marginal lands [7]. At the same time, in the publications of the authors [8], it has been determined that miscanthus giganteus and switchgrass are the most productive, in terms of biomass, energy crops with high economic indicators of its efficiency. These researches correspond with the results obtained by other authors [9-11]. According to their research, it has been 
established that high yields of energy-intensive biomass and switchgrass seed can be achieved through special agricultural measures of growing and pre-sowing seed preparation. Besides, it is necessary to take into account the weather conditions and the identified ways of reducing their negative impact on switchgrass phytocenosis. Another publication gives the economic effectiveness of the switchgrass biomass production, taking into account the optimized cultivation technology [12].

In the formation of the switchgrass yield, along with the weather conditions of cultivation period and varietal traits, a significant contribution belongs to the yield structure. Yield structure includes productivity elements: plant density per unit area, number and height of stems, number and weight of seeds in panicle, weight of 1000 seeds, etc. [13]. That is why in order to obtain high yields of biomass or seeds, it is necessary to ensure the most optimal ratio of all elements of the yield structure of energy crops, in particular, switchgrass.

A considerable number of foreign scientific works is devoted to the research of the targeted issue. Significant contribution to the solution of the problem of the use of biologically renewable plant resources application, including energy crops, their introduction, selection and improvement of the cultivation technology elements have been made by V. L. Kurylo, M. V.Roiik, D. B. Rakhmetov, M. Ya. Humentyk, V. A. Doronin, V. V. Dumych, S. D. Orlov, H. H. Heletukha, T. A. Zheliezna, H. M. Kaletnik, S. M. Mandrovska and others (Table 1).

However, information concerning the ways of obtaining high switchgrass yield is insufficient in order to understand the regularities of its seed productivity formation in Ukraine. In view of the above-mentioned facts, it can be argued that the evaluation of the breeding material according to the economically valuable traits is of high importance for creation of new high-yielding varieties for the following establishing of the effective energy plantations.

\section{Research material and methods}

Field experiments were conducted during 2015-2019 period with the collection of energy crops of Poltava State Agrarian Academy, which belongs to the central part of the Forest-Steppe of Ukraine according to the zonal distribution. 
Analysis of the research results

\begin{tabular}{|c|c|}
\hline Authors & Short description of the research results \\
\hline $\begin{array}{l}\text { Kulyk M., } \\
\text { Shokalo N., } \\
\text { Dinets O. [14] }\end{array}$ & $\begin{array}{l}\text { The impact of the morphometric indicators of energy crops } \\
\text { (switchgrass, miscanthus, sida, castor, rumex, etc.) on their } \\
\text { productivity has been established. }\end{array}$ \\
\hline $\begin{array}{l}\text { L. E. Moser and } \\
\text { K.P. Vogel [15] }\end{array}$ & $\begin{array}{l}\text { It has been determined that all switchgrass varieties originating } \\
\text { from South America have the best adaptive reactions to the } \\
\text { conditions of the southern territories of Eurasia. They will also be } \\
\text { productive in the northern Europe, but their cold resistance will be } \\
\text { less in comparison with varieties of North American origin. }\end{array}$ \\
\hline $\begin{array}{l}\text { Rakhmetov D.B., } \\
\text { Verhun O. M., } \\
\text { Rakhmetova S. } \\
\text { O. [16] }\end{array}$ & $\begin{array}{l}\text { It has been established that while growing introduced switchgrass } \\
\text { varieties, their morphometric parameters should be taken into } \\
\text { account as a result of adaptation to the new cultivation conditions. }\end{array}$ \\
\hline Kulyk M. [17] & $\begin{array}{l}\text { It has been determined that the yield of switchgrass biomass } \\
\text { depends on the stem density, to a lesser extent on the stem height } \\
\text { and the number of leaves on it. }\end{array}$ \\
\hline $\begin{array}{l}\text { Kulyk M. I., } \\
\text { Rozhko I. I. [18] }\end{array}$ & $\begin{array}{l}\text { It has been determined that the yielding properties and sowing } \\
\text { qualities of switchgrass seeds depend on the weather conditions of } \\
\text { the cultivation period. }\end{array}$ \\
\hline $\begin{array}{l}\text { Kulyk M., } \\
\text { Rozhko I., } \\
\text { Kurylo V., } \\
\text { at all. [19] }\end{array}$ & $\begin{array}{l}\text { It has been established that the seed productivity is determined } \\
\text { by the number of twigs and seeds on the plant, their weight. Seed } \\
\text { yield depends on the height of the stem and the length of the flag } \\
\text { leaf to a lesser extent. This trait is distinctive to plants both on } \\
\text { productive soils and on marginal lands. }\end{array}$ \\
\hline $\begin{array}{l}\text { Moroz O. V., } \\
\text { Smirnykh V. M., } \\
\text { Kurylo V. L., } \\
\text { at all. [20] }\end{array}$ & $\begin{array}{l}\text { It has been found out that in Ukraine, varieties Sunburst and } \\
\text { Cave-in-Rock of the second vegetation year produce seed } \\
\text { productivity of } 0.597 \text { and } 0.373 \mathrm{t} / \text {, respectively. }\end{array}$ \\
\hline $\begin{array}{l}\text { Wolf D. D. and } \\
\text { D. A. Fiske [21] }\end{array}$ & $\begin{array}{l}\text { It has been determined that switchgrass seed productivity varied } \\
\text { in the range of } 220-560 \mathrm{~kg} / \mathrm{ha} \text {, and in some cases can reach } 1000 \\
\mathrm{~kg} / \mathrm{ha}\end{array}$ \\
\hline Orlov S. D. [22] & $\begin{array}{l}\text { Breeding specimens of switchgrass 737-10 (P. v. L.) Cave-in-Rock } \\
\text { / } 377 \text {-10 (P. v. L.) Alamo, 398-10 (P. v. L.) Sunburst / 737-10 / (P. } \\
\text { v. L.) Cave-in-Rock, 1025-10 (P. v. L.) Forestburg / 737-10 (P. v. } \\
\text { L.) Cave-in-Rock have been selected. They are a valuable source } \\
\text { for creating new domestic hybrids and varieties. }\end{array}$ \\
\hline
\end{tabular}


The climate of the experiment is moderate continental, with warm summers and moderate cold winters. January average temperature is $-4^{\circ} \mathrm{C} \ldots-8^{\circ} \mathrm{C}$, and July $-+16 \ldots+22^{\circ} \mathrm{C}$. Precipitation is about $500 \mathrm{~mm}$ per year, with frequent droughts during spring - summer period.

The soil cover of the experiment plots consists of podzolized chernozem having the following characteristics: humus content $-3.85 \%$, soil nitrogen $-214.0 \mathrm{mg}$ per $1 \mathrm{~kg}$ of soil, phosphorus $-148.7 \mathrm{mg}$ per $1 \mathrm{~kg}$ of soil, potassium - $94.3 \mathrm{mg}$ per $1 \mathrm{~kg}$ of soil, $\mathrm{pH}-7.6$.

The predecessor of switchgrass is wild grasses, agro-technology of cultivation is generally accepted for the cultivation area, in accordance with the scientific and practical recommendations [23].

The object of research was switchgrass varietal specimens of foreign and Ukrainian plant breeding: Zoriane - conditional standard (c. st.), Cavein-Rock, Morozko and Liniia 1307. These varieties have corresponding characteristics [24-25].

The research aim is to study switchgrass varietal specimens in terms of economically valuable traits, and to distinguish among them the most yielding with high yield of certified seed in relation to the weather conditions of the vegetation period by the HTC (hydrothermal coefficient).

Research tasks are the following:

1. to determine the variability of quantitative indicators of the generative part of plants of switchgrass varietal specimens, depending on the cultivation conditions;

2. to determine the impact of the cultivation conditions on weight of 1000 seeds, to determine the most adaptive varieties;

3. to find out the impact of the cultivation conditions by HTC on productivity and yield of switchgrass certified seed according to the investigated varietal specimens.

The experiment plots were established according to the methodology of agronomy research [26], with a randomized placement of four time repetition in the soil with low content of humus determined by the method of Turin $(3.9 \%)$, characterized by the following agrochemical parameters: nitrogen, phosphorus and potassium content is increased.

Quantitative indicators of vegetative and generative parts of plants of each variety were determined by the method of sampling diagonally of the plot in the fourfold repetition (50 plants per plot), with 
subsequent determination of the average indicator by the calculation results [27].

Evaluation of switchgrass varietal samples by economic traits, in particular, the number of plants and seeds per plant, the weight of seeds from one plant and others, was carried out in accordance with the scientific methods [28]. The seed size by the weight of 1000 seeds was studied according to the generally-accepted methods [29].

Accounting of switchgrass yield was done according to the methods [30]: at the time of the vegetation completion, sheaf samples were selected diagonally from the plot of $1 \mathrm{~m}$ (running meter) in the fourfold repetition, from which the seeds were threshed and weighed before-, and after cleaning from impurities- parts of panicle twigs, seed scales, etc. The research results were analyzed by the methods of variation statistics and, using the analysis of variance in Statistica 6.0, the least significant difference (LSD) has been determined according to the significance level $(\mathrm{p}<0.05)$.

\section{Research results and discussion}

Throughout the research years, the hydrothermal coefficient (HTC) during the switchgrass vegetation period varied from 0.6 to 1.4. The least favorable (arid) weather conditions were during the 2017 and 2019 vegetation period, the weather conditions in 2015 and 2018 were close to the optimum value by the HTC (the HTC is close to 1), and 2016 was excessively moisty (HTC was more than 1.2). Figure 1-2.

Weather conditions and varietal traits affected the quantitative indicators of the vegetative part of switchgrass plants (figure 3-4).

Among the studied varieties, Cave-in-Rock was characterized by the greatest plant height $(173.3 \mathrm{~cm})$, variety Morozko produced significantly shorter stems $(154.5 \mathrm{~cm})$, plant height of Liniia 1307 (170.3) was at the conditional standard level. According to the number of stems, Liniia 1307, varieties Zoriane and Cave-in-Rock have been distinguished. They form plant density more than 300 pieces/running meter, this indicator of variety Morozko was at the level of 287.8 pieces/running meter.

Variety Zoriane and Liniia 1307 have been distinguished according to the number of leaves on the stem (more than $51.0 \mathrm{~cm}$ ) and internodes (more than 8.5 pcs.), this indicator of other varieties was significantly lower. 
Maksym Kulyk, Olha Dinets, Ilona Rozhko

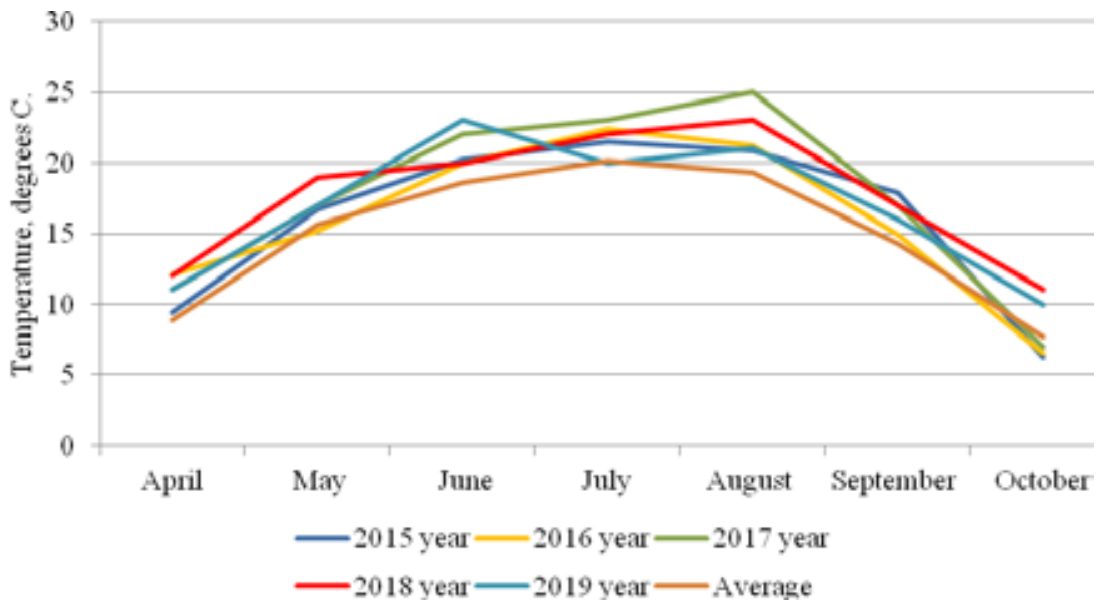

Figure 1. Weather conditions (air temperature) of the switchgrass vegetation period, 2015-2019

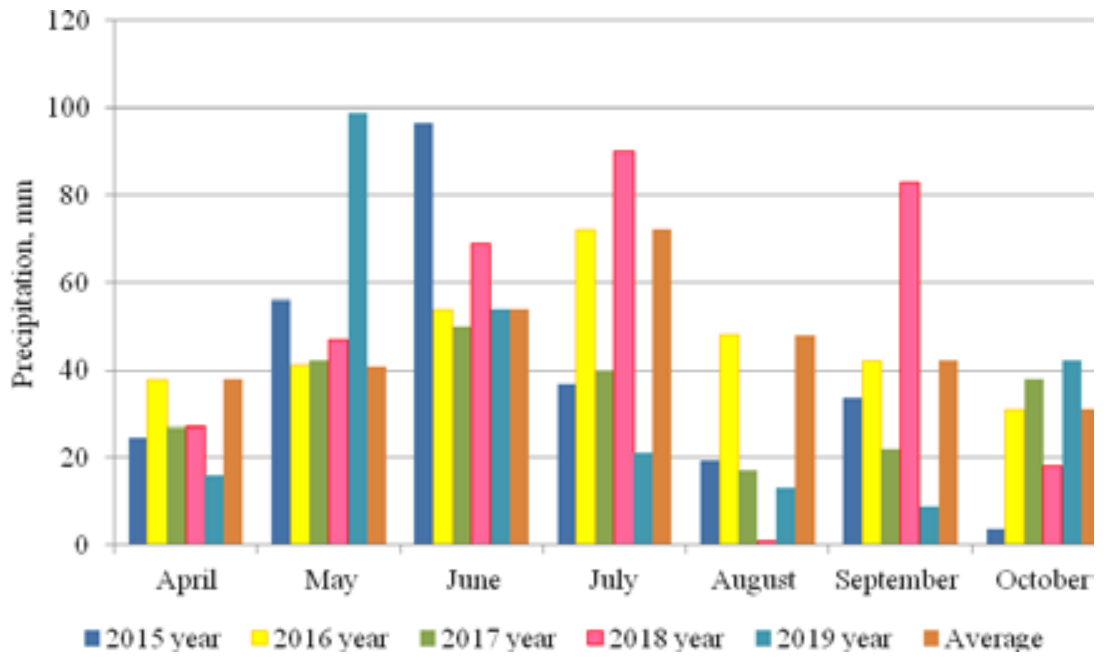

Figure 2. Weather conditions (precipitation) of the switchgrass vegetation period, 2015-2019 


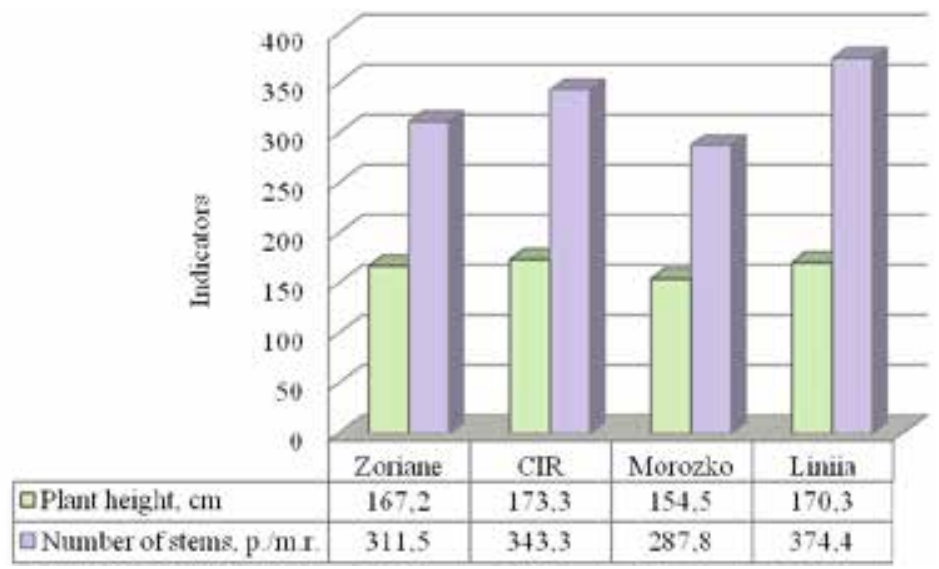

$\mathrm{LSD}_{05}$ (Plant height, cm) 3.4; $\mathrm{LSD}_{05}$ (Number of stems, pcs./r. m) 21.3

Figure 3.Quantitative indicators of the vegetative part of switchgrass plants (plant height and number of stems), average for 2015-2019

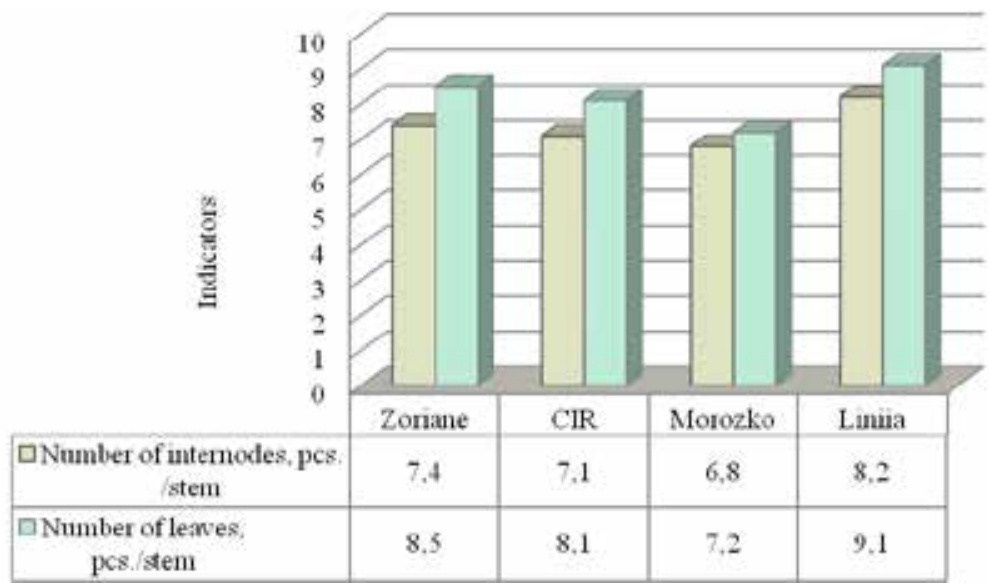

$\mathrm{LSD}_{05}$ (Number of internodes, pcs./stem) $0.3 ; \mathrm{LSD}_{05}$ (Number of leaves, pcs./stem) 0.2

Figure 4. Quantitative indicators of the vegetative part of switchgrass plants (number of internodes of leaves on the stem), average for 2015-2019 
Maksym Kulyk, Olha Dinets, Ilona Rozhko

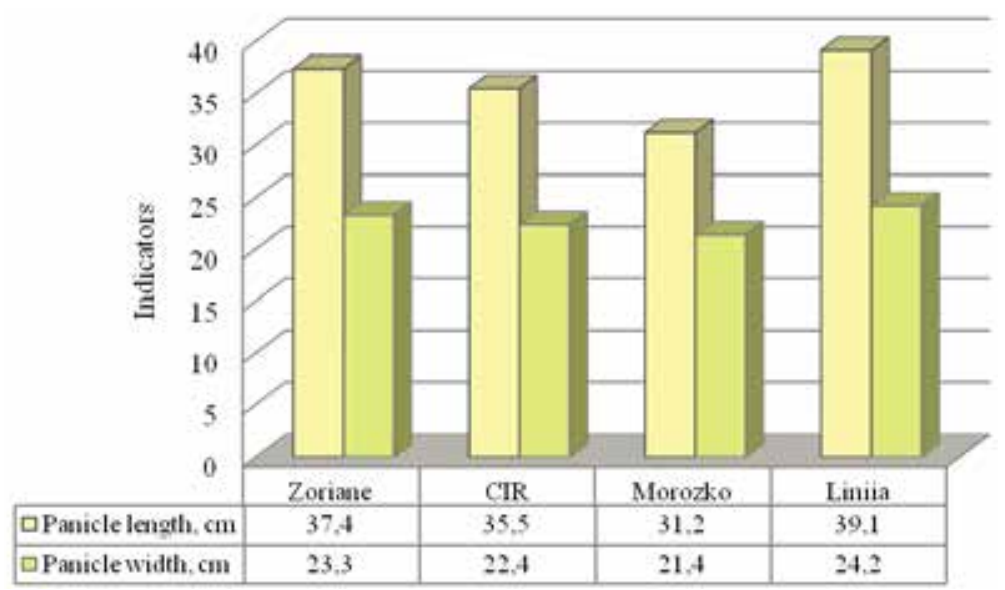

$\mathrm{LSD}_{05}$ (Panicle length, $\mathrm{cm}$ ) 1.1; LSD 05 (Panicle width, $\mathrm{cm}$ ) 0.4

Figure 5.Quantitative indicators of the generative part of switchgrass plants (panicle length and width), average for 2015-2019

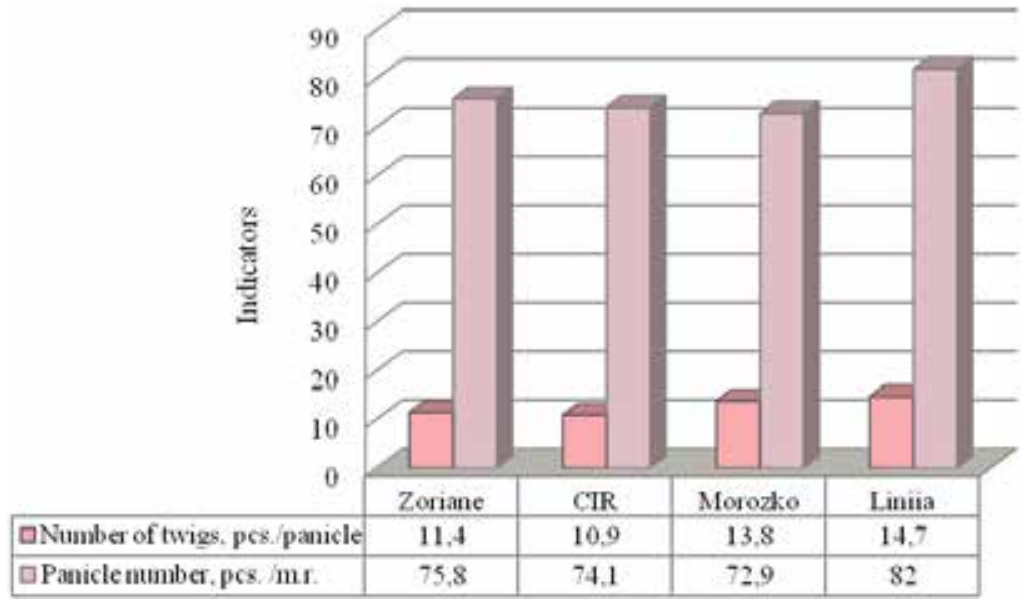

$\mathrm{LSD}_{05}$ (Number of twigs, pieces) 0.6; $\mathrm{LSD}_{05}$ (Number of panicles, pieces./м.П.) 5.3

Figure 6. Quantitative indicators of the generative part of switchgrass plants (the number of twigs of the first order and panicles) average for 2015-2019 
The yield structure elements of the generative part of the plants (length and width of panicle, their number, as well as the number of twigs of the first order, and the weight of seeds from panicle) varied widely, and had the following indicators (Figures 5-6).

According to the morphometric parameters, variety Cave-in-Rock and Liniia 1307 showed the highest indicators, compared with the conventional standard. These varietal samples formed the largest seed weight from panicles that resulted in high seed productivity.

The weight of 1000 seeds depends on the impact of the weather conditions of the vegetation period and the variety properties. Significant variation in the seed size of varietal specimens has been determined, which averaged 1.15-1.75 g during the research years (Figure 7).
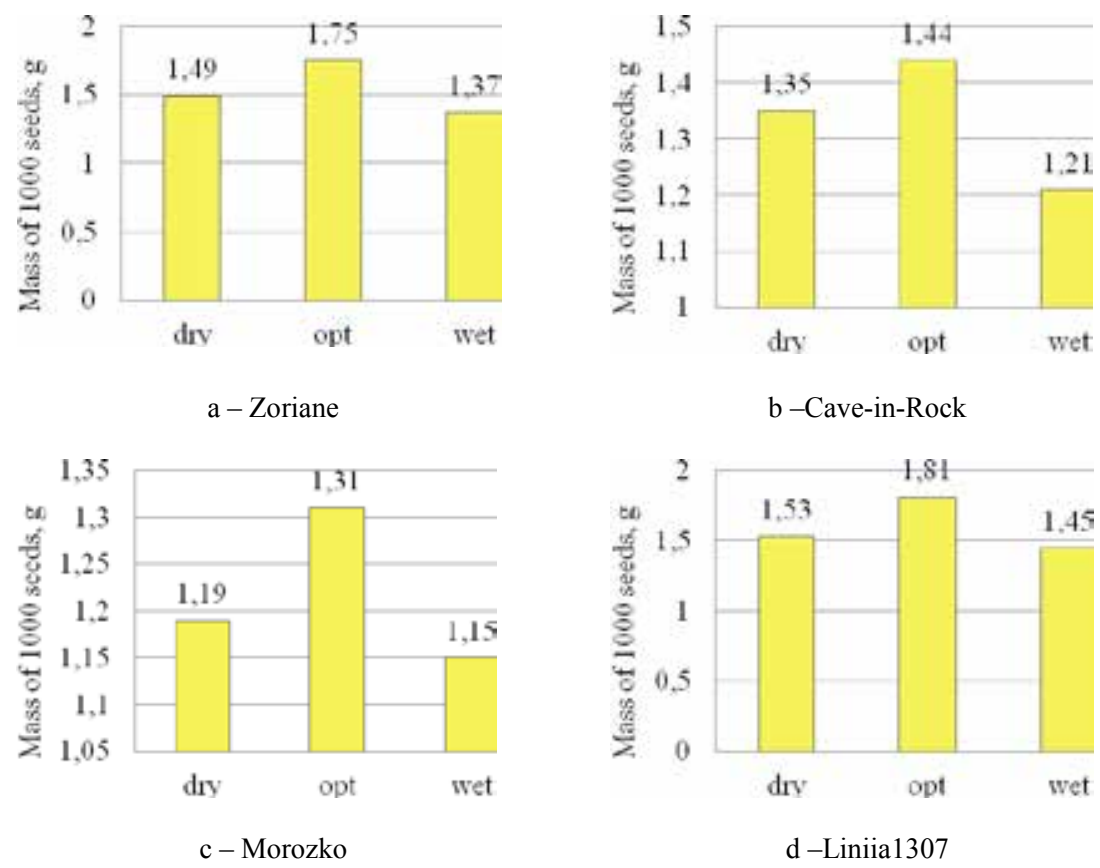

Note: dry - dry conditions, opt - optimal conditions, wet - wet conditions.

Figure 7. Weight of 1000 seeds depending on the cultivation conditions, average for 2015-2019 
In the optimal years, under the water availability, variety Morozko formed minimum weight of 1000 seeds $(1.31 \mathrm{~g})$, variety Cave-in-Rock formed significantly bigger weight $(1.44 \mathrm{~g})$, and the maximum weight was provided by Zoriane and Liniia 1307, respectively 1.75 and $1.81 \mathrm{~g}$.

It has been determined that in the dry conditions of the vegetation period, the weight of 1000 seeds of the studied varieties varies in the range from 1.19 to $1.53 \mathrm{~g}$, the periods of excessive moisture - from 1.15 to $1.45 \mathrm{~g}$, and in the conditions close to optimal, seeds size will be the largest - from 1.31 to $1.81 \mathrm{~g}$. Variety Zoriane and Liniia 1307 produce the weightiest seeds. A slight variation of this characteristic (V) has been established for these varietal specimen, respectively 1.81 and $2.75 \%$. An average variation of variety Morozko (12.4\%) and a considerable variation of variety Cavein-Rock (25.6\%) have been established as well.

By establishing the correlation between the quantitative indicators of the generative part of the plants, it has been found that the indicator of weight of 1000 seeds has strong relations with the number of twigs of the first order ( $\mathrm{r} 0.78 \ldots 0.81$ ), and the average - with the length ( $\mathrm{r} 0.31 \ldots 0.36)$ and the width of panicle ( $\mathrm{r} 0.41 \ldots 0.43$ ). This trait is typical for all switchgrass varieties.

The correlation between the quantitative indicators of the generative part of the plants and the seed yield (SY) demonstrate that the indicator of weight of 1000 seeds has average relations with SY (r $0.35 \ldots 0.44)$, the number of twigs of the first order and SY has strong relations ( $\mathrm{r} 0.73 \ldots 0.77$ ), the number of panicles - strong relations $(0.69 \ldots 0.72)$, and average relations with panicle length ( $\mathrm{r} 0.30 \ldots 0.32)$ and width ( $\mathrm{r} 0.31 \ldots 0.35)$. This regularity was observed for all studied switchgrass varieties.

In general, throughout the research years, the highest yields of certified seed were formed by the variety Zoriane ( 25.0 and $26.4 \mathrm{~kg} /$ running meter) and Liniia 1307 (25.4 and $26.6 \mathrm{~kg} /$ running meter) in the dry and optimal years according to HTC. Seed yield was significantly lower for all varietal specimens in the conditions of excessive moistening during the vegetation period (Figure 8).

Compared to the conditional standard (variety Zoriane) and other varietal specimens, the newly created Liniia 1307 provided significantly higher yields of certified seed with a slight variation of the trait. A similar dependence was observed for variety Cave-in-Rock, but with a much lower seed yield. 

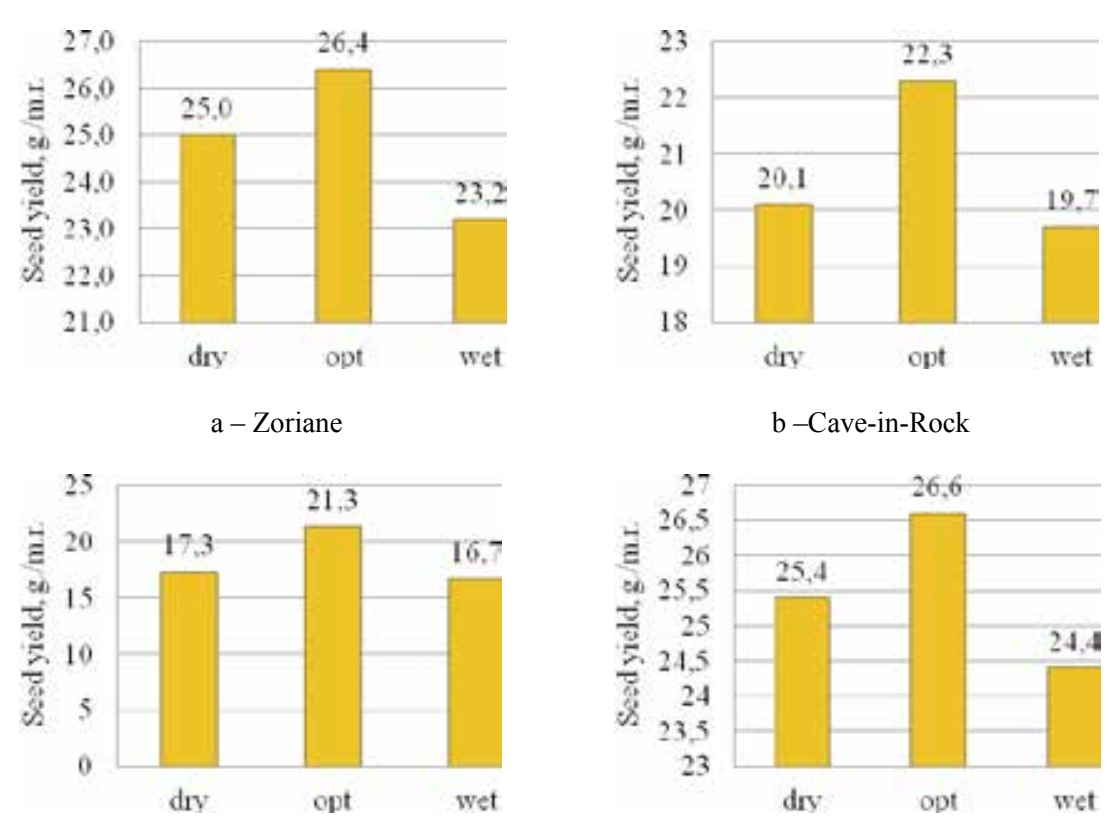

Note: dry - dry conditions, opt - optimal conditions, wet - wet conditions

\section{Figure 8. Yield of certified switchgrass seed depending on the cultivation conditions, average for 2015-2019}

Among the studied varieties, the lowest seed yield was provided by the variety Morozko, both in optimal moisty, and in arid and excessively moisty vegetation periods. A similar tendency was observed in the variety Cavein-Rock, but with higher yields of certified seed. Variety Zoriane and Liniia 1307 form a significantly higher yield level in both arid and optimal years according to HTC.

\section{Conclusions}

1. In the conditions of the central Forest-Steppe of Ukraine, switchgrass plants are able to form seed since the first vegetation year. It has been established that along with the weather conditions of the vegetation period, varietal traits greatly affect productivity and yield of the certified seed. Variety Zoriane and Liniia 1307 formed the highest productivity and yield of 
certified seed, respectively, 26.4 and $26.6 \mathrm{~kg} / \mathrm{running}$ meter, which may be valuable for further breeding activity.

2. It has been determined that in the drier or close to the optimum conditions of the switchgrass vegetation period (according to the HTC), the seed yield will be much higher in comparison with more humid conditions. This is typically for all switchgrass varieties, which characterizes their average plasticity to the cultivation conditions.

3. Variety Zoriane and Liniia 1307 have the most stable manifestation in terms of the weight of 1000 seeds, which has an average impact on the seed yield by the coefficient of correlation; other varieties have an average and strong coefficient of variation according to this indicator. This trait should be used in plant breeding.

4. Quantitative indicators of the generative part of switchgrass plants make a substantial contribution to the level of seed yield. The seed yield of switchgrass varietal specimens by the determination coefficient (d) depends on $53-59 \%$ the number of twigs of the first order, $48-52 \%$ - the number of panicles, $12-21 \%$ - the size of seeds, and $6-12 \%$ - the length and width of panicle.

The perspectives for further researches will be to study the impact of pre-sowing seed preparation measures on sowing quality of the seed material in order to reduce the adverse effect of the weather conditions of the initial stages of seed germination.

\section{References:}

1. Rahman M.M. at all. (2014). Extension of energy crops on surplus agricultural lands: A potentially viable option in developing countries while fossil fuel reserves are diminishing. Renewable and Sustainable Energy Reviews, no. 29, pp. 108-119.

2. Lesschen J.P., Elbersen H.W., Poppens R. at all. (2012). The financial and GHG cost of avoiding ILUC in biomass sourcing - a comparison between switchgrass produced with and without ILUC in Ukraine. 20th European Biomass Conference and Exhibition, 18-22 June 2012, 2012-06-18/2012-06-22. Available at: https://library.wur.nl/WebQuery/wurpubs/433099 (accessed 31.10.2019).

3. Kulyk M., Galytska M., Samoylik M., Zhornyk I. (2019). Phytoremediation aspects of energy crops use in Ukraine. Agrology, vol. 2(1), pp. 65-73. Available at: https://doi.org/10.32819/2617-6106.2018.14020 (accessed 31.10.2019).

4. Monti A., Fazio S., Venturi G. (2009). The discrepancy between plot and field yields: Harvest and storage losses of switchgrass. Biomass Bioenergy, no. 33, pp. 841-847. DOI: 10.1016/j.biombioe.2009.01.006 
5. Petrychenko S.M., Herasymenko O.V., Honcharuk H.S. ta in. (2011). Perspektyvy vyroshchuvannia svitchhrasu yak alternatyvnoho dzherela enerhii v Ukraini. Tsukrovi buriaky [Prospects for Growing Lighting as an Alternative Energy Source in Ukraine. Sugar beet], no. 4, pp. 13-14.

6. Kalinichenko O.V., Kulyk M.I. (2018). Ekonomichna efektyvnist vyroshchuvannia prosa prutopodibnoho (svitchhrasu) v umovakh Lisostepu Ukrainy [Economic efficiency of growing millet in the conditions of the Forest-Steppe of Ukraine]. Ekonomika APK. vol. 11, pp. 19-28. Available at: http://eapk.org.ua/contents/2018/11/19 (accessed 31.10.2019).

7. Kalinichenko A., Kalinichenko O., Kulyk M. (2017). Assessment of available potential of agro-biomass and energy crops phytomass for biofuel production in Ukraine: Odnawialne źródła energii: teoria i praktyka. Monograph / pod red. I. Pietkun-Greber, P. Ratusznego, Uniwersytet Opolski. (tom II), pp. 163-179.

8. Kulyk M.I., Syplyva N.O., Rozhko I.I. (2018). Urozhainist ta efektyvnist vyrobnytstva biomasy enerhetychnykh kultur zalezhno vid elementiv tekhnolohii vyroshchuvannia [Yields and efficiency of energy crops biomass production depending on the elements of the cultivation technology]. Taurian Scientific Bulletin. Kherson, vol. 104, pp. 11-22. Available at: http://tnv-agro.ksauniv.ks.ua/ archives/104_2018/26.pdf (accessed 17.10.2019).

9. Kulyk M.I. (2016). Enerhetychnyi potentsial ta ekonomichna efektyvnist vyrobnytstva fitomasy svitchhrasu dlia biopalyva. Naukovi dopovidi Natsionalnoho universytetu bioresursiv i pryrodokorystuvannia Ukrainy [Energy potential and economic efficiency of switchgrass phytomass production for biofuel. Scientific reports of National University of Bioresources and Natural Resources Use of Ukraine], no. 4. Available at: http://journals.nubip.edu.ua/index.php/Dopovidi/ article/view/6971/6769 (accessed 30.10.2019).

10. Kulyk M.I., Rozhko I.I. (2018). Zakonomirnosti formuvannia urozhainosti nasinnia prosa prutopodibnoho v umovakh Lisostepu Ukrainy. Visnyk Poltavskoi derzhavnoi ahrarnoi akademii [Regularities of yield formation of switchgrass seeds in the conditions of Forest-Steppe of Ukraine]. Bulletin of the Poltava State Agrarian Academy, vol. 4(91), pp. 85-99. Available at: https://www.pdaa.edu.ua/sites/default/files/visnyk/2018/04/15.pdf (accessed 30.10.2019).

11. Taranenko A., Kulyk M., Galytska M., Taranenko S. (2019). Effect of cultivation technology on switchgrass (Panicum virgatum L.) productivity in marginal lands in Ukraine. Acta Agrobot. 72(3): 1786. Available at: https://doi.org/ 10.5586/aa.1786 (accessed 30.10.2019).

12. Kalinichenko O.V., Kulyk M.I. (2018). Economic efficiency of switchgrass growing in the conditions of the Forest-Steppe of Ukraine. Economica APK. Issue 11, pp. 19-28. Available at: http://eapk.org.ua/contents/2018/11/19 (accessed 31.10.2019).

13. Kulyk Maksym, Shokalo Natalia, Dinets Olha (2019). Morphometric indices of plants, biological peculiarities and productivity of industrial energy crops. Development of modern science: the experience of European countries and prospects for Ukraine: monograph / edited by authors. 3rd ed. Riga, Latvia: «Baltija 
Publishing», pp. 411-431. URL: https://doi.org/10.30525/978-9934-571-78-7 (accessed 17.10.2019).

14. Kulyk Maksym, Shokalo Natalia (2018). Impact of plant biometric characteristics on seed productivity of castor-oil plant and switchgrass depending upon weather conditions of the vegetation period in the Forest-steppe of Ukraine. Relevant issues of development and modernization of the modern science: the experience of countries of Eastern Europe and prospects of Ukraine: monograph/edited by authors. 1rded. Riga,Latvia:«BaltijaPublishing»,pp. 182-204. URL: http://www.baltijapublishing.lv/download/all-science/10.pdf (accessed 17.10.2019).

15. Moser L.E. and K.P. Vogel (1995). Switchgrass, Big Bluestem, and Indiangrass. In: An introduction to grassland agriculture. Iowa University Press, pp. $409-420$.

16. Rakhmetov D.B., Verhun O.M., Rakhmetova S.O. (2014). Panicum virgatum L. - perspektyvnyi introdutsent $\mathrm{v}$ Natsionalnomu botanichnomu sadu im. M. M. Hryshka NAANU. Introduktsiia roslyn [Panicum virgatum L. is a promising introducer in the National Botanical Garden named after MM Grishko of NAASU. Introduction of plants], vol. 3(63), pp. 4-12.

17. Kulyk M.I. (2015). Adaptivny’j potenczial prosa prut' evidnogo v usloviyakh Ukrainy'[Adaptive potential of switchgrass in the conditions of Ukraine]. Vestnyk Kurhanskoi HSKhA, no. 1(13), pp. 28-30. (in Russian).

18. Kulyk M.I., Rozhko I.I. (2018). Urozhaini vlastyvosti ta posivni yakosti nasinnia prosa prutopodibnoho zalezhno vid umov vyroshchuvannia[Yields and sowing qualities of millet seeds, depending on growing conditions]. Bulletin of the Poltava State Agrarian Academy, vol. 2(89), pp. 78-84. Available at: http://journals.pdaa.edu.ua/visnyk/article/view/206 (accessed 31.10.2019).

19. Kulyk Maksym, Rozhko Ilona, Kurylo Vasyl, at all. (2018). Impact of the soil and climate conditions on the formation of the crop yield and germinating power of the switchgrass (Panicum virgatum L.) seeds. Journal of Research and Applications in Agricultural Engineering. vol. 63(4), pp. 101-105. Available at: http://www.pimr.poznan.pl/biul/2018_4_KRK.pdf (date of accessed 31.10.2019).

20. Moroz O.V., Smirnykh V.M., Kurylo V.L. ta in. (2011). Svitchhras yak nova fitoenerhetychna kultura [Svetgrass as a new phyto-energy culture]. Sugar beets, vol. 3(81), pp. 12-14.

21. Wolf D.D. and D.A. Fiske. Forages (1995). Planting and managing switchgrass for forage, wildlife, and conservation. Virginia Cooperative Extension, pp. $418-423$.

22. Orlov S.D. (2013). Osoblyvosti proiavu biolohichnykh, hospodarskykh oznak roslyn Panicum virgatum (svitchhras) z metoiu stvorennia sortiv z vysokoiu enerhetychnoiu tsinnistiu $\mathrm{v}$ Lisostepovii zoni Ukrainy [Features of manifestation of biological, economic features of plants Panicum virgatum (switchgrass) in order to create varieties with high energy value in the Forest-steppe zone of Ukraine]. Scientific papers of the Institute of bioenergy crops and sugar beet, vol. 19, pp. 93-95.

23. Kurylo V.L., Humentyk M.Ya, Honcharuk H.S. at all. (2012). Metodychni rekomendatsii $\mathrm{z}$ provedennia osnovnoho ta peredposivnoho obrobitkiv gruntu 
i sivby prosa lozovydnoho [Methodical recommendations for the basic and presowing tillage and sowing of millet vine]. Kiev: Institute of Bioenergy Crops and Sugar Beet, $28 \mathrm{p}$.

24. Okhorona prav na sorty roslyn: Biuleten (2015). Derzhavna veterynarna ta fitosanitarna sluzhba Ukrainy [Protection of rights to varieties grew: Bulletin. State Veterinary and Phytosanitary Service of Ukraine].Kiev: Ukrainian Institute for Plant Variety Examination. PP "Ostintech", vol. 3, pp. 221-222.

25. Elbersen H.W., Christian D.G., Bassen N.El, and D. Van Den Berg (2001). Switchgrass variety choice in Europe. Aspects of Applied Biology, no. 65, pp. 21-28.

26. Moiseichenko V.F., Yeshchenko V.O. (1994). Osnovy naukovykh doslidzhen $\mathrm{v}$ ahronomii [Fundamentals of scientific research in agronomy]. Kiev : High school, $334 \mathrm{p}$.

27. Tkachyk S.O.; ukl. Kostenko N.P., Hryniv S.M. ta in. (2016). Metodyka provedennia ekspertyzy sortiv roslyn hrupy tekhnichnykh na vidminnist, odnoridnist i stabilnist [Methods of examination of plant varieties of the technical group for difference, homogeneity and stability]. Ukrainskyi instytut ekspertyzy sortiv roslyn, 2-he vyd., vypr. i dop. Vinnytsia, 188 p. ISBN 978-966-924-601-1

28. Kulyk M.I., Rakhmetov D.B., Kurylo V.L. (2017). Metodyka provedennia polovykh ta laboratornykh doslidzhen $\mathrm{z}$ prosom prutopodibnym (Panicum virgatum L.) [Methods of conducting field and laboratory studies with rod-shaped millet (Panicum virgatum L.)]. Poltava: RVV PDAA. 24 p.

29. Nasinnia silskohospodarskykh kultur. Metody vyznachannia yakosti: DSTU 4138-2002 [Seeds of agricultural crops. Methods for determining the similarity of DSTU 4138-2002 [Chynnyi vid 2004-01-01]. Kiev: Derzhspozhyvstandart Ukrainy, 173 p. (Derzhspozhyvstandart Ukrainy).

30. Kulyk M., Elbersen W. (2012). Methods of calculation productivity phytomass for switchgrass in Ukraine. Poltava. $10 \mathrm{p}$. 